\title{
Labour trafficking in Chinese restaurants in the Netherlands and the role of Dutch immigration policies. A qualitative analysis of investigative case files
}

\author{
Masja van Meeteren ${ }^{1}$ (D) Ellen Wiering ${ }^{1}$ \\ Published online: 3 August 2019 \\ (C) The Author(s) 2019
}

\begin{abstract}
Scholars have found that many migrants are vulnerable to exploitation and that there are many immigrants among victims of extreme forms of labour exploitation. In the Global North, empirical studies have scrutinized the link between irregular migration and labour trafficking, yet empirical studies that focus on labour schemes involving regular migrants remain scarce. Drawing on a qualitative analysis of 8 investigative police files of labour trafficking involving regular migrants in the Chinese catering industry in the Netherlands, this study investigates the mechanisms through which exploitation comes about and is sustained. It is concluded that exploitation is the result of the ways in which both the employers and the victims manoeuvre the space provided by immigration policies. Employer-bounded residence and work permits emerged as an especially important contributor to the initiation and continuation of exploitative situations. Policymakers should be highly aware of the vulnerabilities of temporary labour migrants' positions created by such policy arrangements. Future research is needed in order to create a better understanding of how exploitative work situations develop and are sustained, and the role different factors such as immigration policies play in such processes.
\end{abstract}

Traditionally, research on human trafficking and modern slavery has focused primarily on sex trafficking. As a result, other types of trafficking have been largely overlooked [54]. Although the body of knowledge on labour trafficking is steadily growing, a recent systematic review on labour trafficking indicated that this field of research is still immature [8]. More specifically, labour exploitation of migrant workers has been studied more prominently in a different - and rather separate - strand of literature on

Masja van Meeteren

m.j.van.meeteren@law.leidenuniv.nl

1 Department of Criminology, Leiden Law School, Leiden University, Steenschuur 25, 2311

ES Leiden, The Netherlands 
(irregular) migration and the unintended consequences of migration control. However, although this literature demonstrates how labour migrants often work under unfavourable conditions, this is generally not approached through the lens of trafficking or crime [44]. Given the rather separate research traditions of trafficking research on the one hand and migration research on the other, it is not surprising that the link between migration and labour trafficking has not received much research attention [44].

Although vulnerability to labour trafficking is not restricted to migrants, and not all migrants are vulnerable to labour trafficking, it has been argued that some categories of migrants are particularly vulnerable to labour trafficking [15]. Based on a review of the literature as well as expert interviews, [15]: 20 indicate that irregular migrants and refused asylum seekers are particularly susceptible to labour trafficking. Indeed, scholars usually associate the exploitation or trafficking of migrants with irregular migration [44, 45]. However, scholars have also noted that "many of the workers who would fit the designation of persons trafficked for labour exploitation migrated freely and legally" ([41]: 204). Dwyer et al. [15] also observe that although irregular migrants are particularly at risk, regular migrants may also be vulnerable to labour trafficking.

Moreover, from the somewhat separate strand of literature on labour migration, a growing body of studies emerges that emphasize that all migrant groups with restrictions placed on their labour market entry and access to welfare can be subjected to more exploitative forms of work [29]. Lewis et al. [29] coin the notion of hyper-precarity to characterize the lives of these exploited migrants that emerge "from the ongoing interplay of neoliberal labour markets and highly restrictive immigration regimes." Ruhs [35] likewise argues that it is important to study the consequences of the systems governments have in place to regulate migrant labour, and the restrictions they place on migrant rights.

Based on the foregoing, it has become clear that other types of migrants - besides irregular migrants - are vulnerable to extreme forms of exploitation. However, empirical evidence showing how such situations come about, is still lacking, especially concerning those who migrate legally and approached through the lens of labour trafficking. Scholarly understanding largely remains an area of theory and argumentation rather than empirical study. As such, a list of factors, or 'points of vulnerability' [15] has been generated, but it is not yet empirically shown if and how these factors contribute and work together to create an interplay through which exploitation of regular migrants comes about.

The present study attempts to contribute to filling part of this empirical gap. Investigative case files on labour trafficking in the Chinese restaurant industry in the Netherlands are analysed, in order to understand how the exploitative conditions are developed and sustained there, and to explore the role of immigration status and immigration policies in these processes. Migrant workers in Chinese restaurants are especially relevant in the context of exploitation of legal migrants, since they face restrictions on their labour market entry. Moreover, case files on Chinese restaurants constitute a large share of all investigative case files on labour trafficking in the catering industry in the Netherlands [34], a sector that has been frequently associated with exploitation [33]. This qualitative analysis of 8 investigative police files involving legal Chinese migrants, attempts to identify the mechanisms that have played a facilitating role in making labour trafficking come about. Particular attention is paid to the 
relationship between these mechanisms and the labour restrictions connected to the immigration status these regular migrant workers face.

\section{Points of vulnerability to labour trafficking related to migration}

In order to analyse how the exploitative conditions developed and sustained in the cases studied here, it is important to develop a comprehensive picture of factors that could play a role. Therefore, we review the different factors that have been mentioned in the literature related to immigration and exploitation. Aligning with Hynes [21], Lewis (2015) and Dwyer et al. [15] we distinguish between factors prior to arrival and factors after arrival.

Prior to migration, migrants may be vulnerable because of their weak socialeconomic position in their country of origin. Dwyer et al. [15], for example, found a link between family poverty and exploitation. Family members in the origin country who depend on their income, may pressure migrant workers, creating an imperative to work and avoid losing their job [15]. Furthermore, due to increasing migration restrictions, migrants may take increasingly dangerous and more costly migration routes, arriving with debts to be repaid [31]. While dependency on migrant smuggling does not apply to regular migrants, scholars have noted that the fees recruitment agencies charge can create similar effects [52].

Migrant workers are actively recruited because "migrants, especially new arrivals, are seen as being harder workers, more loyal and reliable, and prepared to work longer hours due to their lack of choice and the large volume of available labour at the low end of the labour market" [29, 30]. Amongst new arrivals, employers may even prefer legal migrantion as it can be preferable for employers to create work situations of semi-compliance, where migrant workers are legally resident but in breach of employment restrictions [36]. Semi-compliance is extremely difficult for the state to control and provides employers room to reduce economic costs by violating labour standards, while avoiding fines for illegal employment [36].

Furthermore, if migrants are not recruited with high associated recruitment costs, they usually arrive with mediation of their friends and family members, in other words, through their social networks [50]. While migration scholars have traditionally focused on the positive effects of embeddedness in migrant networks, they increasingly emphasize the negative effects that reliance on migrant networks may foster as well $[1,13$, 32]. In fact, Cranford [11] has shown that dependency on family members may also lead to exploitative situations where family members take advantage of their vulnerable situation.

Furthermore, people may accept exploitation, as a means to an end [48]. Bloch and McKay [5] show that migrants may perceive exploitative labour conditions as a necessary step in their upward labour market mobility. It is something they knowingly accept as being part of the deal. Moreover, labour conditions deemed as exploitative by outsiders may still be attractive to migrants as they offer possibilities to learn and receive training on specific skills that will contribute to their upward labour market mobility (e.g., [5]). Therefore, some perceive exploitative circumstances to be a normal and acceptable component of migration processes [49]. 
After arrival, workers often depend on their employers or intermediaries for housing, insurance, food, and in some cases worker's passports are kept by the trafficker [33]. This situation of multiple dependency is exacerbated and sustained by victims' low social position. Low-skilled labour migrants often do not speak the language of the destination country and have a limited social network mostly comprised of other migrants [49], which makes it difficult to improve their access to information about their labour rights.

An additional factor at play may be related to the mutual expectations. In research conducted by Hiah and Staring [20], Chinese restaurant owners and (former) employees of Chinese restaurants in the Netherlands were interviewed. This study shows that both the employers and the employees did not characterize the labor situation as exploitation. The authors show how restaurant owners and their employees legitimize the exploitative situations based on culturally shared expectations about justice, reciprocity and hierarchical relationships. They argue that it is normal for illegal workers to perform work under poor conditions and for entrepreneurs to make use of their vulnerability. Legal stay is "earned" after having undergone severe working conditions for some time.

Furthermore, many studies have reported how irregular migrants are trapped in labour trafficking situations because they fear that their employer will report their illegal stay to the police if they protest to the exploitative conditions (Ollus, Jokinen and Joutsen 2013). As such, illegal residence status is an important vulnerability factor. However, there is also an increasing body of knowledge on the exploitative effects of temporary labour programs that restrict labour market entry and social rights for migrants. Such programs can create profound inequality for workers on the labour market "which policy-makers implementing these arrangements often ignore" [56]. Wright et al. [56] argue that it is known that - in general - temporary migrant workers constitute a vulnerable group because of their precarious immigration status. Others likewise assert that temporary migration programmes are increasingly criticized for fostering exploitation $[9,15]$.

Workers' dependence on their employers varies depending on the exact design of the work permit system, and in particular on the question of how easy it is to switch jobs [42]. Especially systems that bind workers to specific employers tend to be at risk of fostering exploitation. Workers are not inclined to resist exploitative practices as they believe they have to either accept the exploitation or leave the work situation and become illegal. In this light it is interesting that research has shown that migrants may believe to be better off as relatively 'free' irregular migrants than as temporary migrant workers tied to an abusive employer [17].

According to Lenard and Straehle ([27]: 283-285) temporary labour migration programs that target low-skilled workers are unavoidably exploitative. They postulate four possible sources of exploitation: 1) the inherent vulnerability of the migrant workers themselves; 2) the state's inability or unwillingness to protect migrant workers from contract violations; 3 ) the inclusion of unjust conditions in the contracts themselves; and 4) in particular, the stipulation that bars (most) migrants from transferring their status from 'temporary' to 'permanent'.

\section{Regulating labour migration in the Netherlands}

"Immigration policies of most high-income countries create a number of different types of residence status for different types of migrants, each of which is associated with 
different rights and restrictions" ([35]: 24). In addition, states also regulate the possibilities for switching between different statuses [35]. On the one hand, states create restrictive policies to satisfy the strong public demand for restrictive immigration policies, protecting the host labour market from migrant labour that is thought to compete natives out of a job [28]. On the one hand, policy makers want to satisfy employer demands to fill shortages on the labour market. Temporary migration programmes have often been perceived as a good in-between solution in such debates, giving way to employer demands yet not opening the labour market in full [28].

There are different ways of selecting and admitting migrant workers, but the distinction is generally made between 'worker-driven' and 'employer-driven' selection [42]. 'Worker-driven' migration, does not require a job offer, since work authorisation is given to an individual on the basis of their characteristics (e.g. being highly skilled in a certain area). Employer-driven migration involves a job offer as a precondition for eligibility [42]. Employer-driven schemes allow governments to more actively intervene in the allocation of workers to jobs, and hence contribute to filling specific shortages on the labour market.

The Dutch government prefers stimulating the labour force participation of its own citizens over inviting foreign workers. Labour migration is only perceived desirable for vacancies for which there are no Dutch or European workers available. Therefore, there is a general employer-driven labour scheme. ${ }^{1}$ An exception is made for highly skilled workers, for which a special worker-driven scheme was created [51]. Dutch labour migration schemes are laid down in the law 'Wet Arbeid Vreemdelingen'. For the general employer-driven scheme, Dutch legislation requires employers to adhere to the European Unions's Generalised system of Preferences. This means that when they have a vacancy, they first have to try to find an employee on the Dutch and European labour market. If that is unsuccessful, workers from outside the EFA can be recruited, as long as the terms of employment follow the collective agreement of the profession or sector. The workers in the Chinese restaurants studied here were subjected to these rules which means they could enter the country if they had a job offer from a Dutch restaurant that was willing to apply for a work permit for them. Moreover, their employers had to follow the terms of the collective agreement of the catering industry [55].

The maximum grant period for a first work permit was 3 years. During this period, migrant workers may be deported back to their home country if they lose their job, and hence their job permit. The work permit is applied for by the employer. It allows the migrant worker to switch to another restaurant only if this is part of a chain of restaurants connected to the work permit. After 3 years, a worker becomes eligible for a 5-years permanent residence permit. Only then, do workers have access to the full Dutch labour market and are no longer tied to their employer. On January 1, 2014, this was changed making migrant workers free on the Dutch labour market only after 5 years instead of 3 . In addition, their eligibility is dependent on a number of conditions, including having a job. ${ }^{3}$

\footnotetext{
${ }^{1}$ Over the years, the Dutch government has provided some exceptions to these general rules, including for the recruitment of Asian chefs. Since this exception was not in place during the exploitation reported in the cases studied here, we will not discuss it here.

${ }^{2}$ https://wetten.overheid.nl/BWBR0007149/2018-01-01\#ParagraafII

${ }^{3}$ https://ind.nl/onbepaalde-tijd/Paginas/Onbepaalde-tijd-na-5-jaar-verblijf-in-Nederland.aspx
} 


\section{Labour trafficking and labour legislation in the Netherlands}

In the Netherlands, labour exploitation is criminalized as human trafficking in Article $273 \mathrm{f}$ of the Dutch Criminal Code. The article is an exact translation of the Palermo Protocol.

Whereas human trafficking was for a long time purely associated with sexual exploitation, since 2005, labour exploitation has been recognized as a form of human trafficking as well. When the scope of the human trafficking offense in the Netherlands was expanded, it was not clear whether - apart from that obligation based on the Palermo protocol - this was actually necessary. The investigative services had no idea how many victims there would be. Exploratory literature research pointed at risks for irregular migrants as possible victims [45]. By, now, it is known that labour trafficking does indeed occur in the Netherlands, and not just among irregular migrants [33].

The interpretation of the definition of human trafficking is largely left to case law. Nevertheless, Dutch courts have played a prominent role in further defining guidelines [16]. In 2009, the Supreme Court of the Netherlands ruled that Dutch working standards are decisive, regardless of the experiences of the standards of those involved (Supreme Court, HR 27 October 2009, LJN BI7097; BI7099 and NJ 2010/598). This means that even though all kitchen staff may think that, from their perspective, working conditions are acceptable, they can still qualify as labour trafficking.

In the Netherlands, the Labour Inspectorate (iSZW) is responsible for all violations in the domain of work. The inspectorate has an administrative branch that deals with violations of labour laws (for which fines can be imposed), and an investigative branch that deals with crime in the domain of work, including labour trafficking. In practice though, it is difficult to determine where poor employment conditions end and trafficking begins [14].

In the Netherlands, there is a collective agreement for workers in the restaurant sector which is binding, meaning that it applies to all restaurants. It is for example stipulated that restaurant staff should have an average work week of $38 \mathrm{~h}$ and that all workers are entitled to a holiday leave of 25 days per year. ${ }^{4}$ By exception, workers can work more hours for a short period of time, but they should receive overtime payments for these hours. The lowest possible wage employers in the catering industry were required to pay full-time staff (dishwashers) of 21 years old and up, was 1,524 euro per month before taxes in 2016. The lowest level cook should be paid 1,726 and a souschef 2,199 euro per month in 2016.

\section{Chinese restaurants in the Netherlands}

The first Chinese immigrants arrived in the Netherlands in the early 1900s as sailors in the Dutch merchant fleet [46]. After the Second World War, Dutch-Indonesians, exmilitary personnel and repatriates from former colony Indonesia arrived which increased the demand for south-east Asian food ([20]: 87-88). Between 1970 and 2000 the number of Chinese restaurants increased rapidly, and so has the demand for Chinese restaurant personnel [37].

\footnotetext{
${ }^{4}$ https://www.khn.nl/cao
} 
At present, there are almost 2,000 Chinese restaurants in the Netherlands. Almost every village of reasonable size has its own 'Chinese on the corner' that offers cheap and large meals to either eat in or take away. Whereas the far majority of these restaurants still serves 'Chinese-Indonesian' food aimed at the lower price segments, nowadays, some owners apply different restaurant formulas aiming at higher price segments to be able to cope with the fierce competition that characterizes the market [55]. Although most Chinese Dutch are still (self) employed in the Chinese catering sector, the children of the restaurant owners increasingly choose a different career path [20]. This is one of the reasons why many of these restaurants struggle to find staff and why an increasing number of restaurants closes down every year [25]. This is probably also the reason why many restaurants have tried to recruit kitchen staff directly from China.

\section{Methods}

This paper draws on in-depth qualitative analysis of 8 investigative case files on human trafficking of Chinese chefs from the Dutch Labour Inspectorate and the Public Prosecution's Office. The investigations for these case files started in the period 2013-2015. Within this period, these are all the case files on Chinese restaurants suspected of involvement in labour trafficking. Whereas some of these investigations have led to convictions, others have not or were dismissed earlier in the process. The case files analysed therefore represent different legal situations to be found on what has become known as the 'continuum of exploitation' [38]. Nevertheless, the case files are by no means representative of the Chinese restaurant sector as a whole.

For research on human trafficking, investigative case files constitute 'the most valuable untapped source of information' ([19]:430; [8]). Compared to other countries, Dutch criminal investigations provide exceptionally rich information, in part due to the absence of plea-bargaining $[12,22]$. They contain information about the nature of exploitation and details about victims' and employers' personal histories and motives. Qualitative research based on Dutch case files has been successfully done in various areas, including human smuggling, organized crime, female crime, Jihadism, youth violence, and drug trafficking [2, 12, 23, 24, 39, 47, 53].

The case files consisted of 10 self-identified victims. In many cases there were more suspected victims who did not want to come forward. There were 13 suspects in total. Most restaurants in the files are owned by a man and a woman, in most cases both were seen as suspects. In some cases only the men were singled out. The case files included 28 people that testified as a witness, including (former) co-workers and other restaurant owners. The analysis made use of the transcripts of the different depositions, statements and interrogations of all these individuals (victims, suspects, witnesses). This amounted to 24 interviews with victims, 25 interrogations of suspects and 29 interviews with witnesses. Three case files included secretly recorded conversations between a suspect and the victim. In addition, they included all kinds of other information from house searches (e.g. business records), research in public records, tax records, immigration records etc. 
From now on, the victims in these case files are referred to as victims, even though some of them have not been proven to be a victim in a court of law. They see themselves as a victim and reported themselves as such to the authorities. The testimonies were all treated as valid individual perspectives, regardless of the legal outcome of the case. Suspects are referred to as suspects or employers and not as perpetrators or traffickers even though some have been labelled as such by a court of law. All individuals have been given popular Chinese names as pseudonyms, the assignment of which took place completely at random. Any cultural or regional connotations are unintentional.

The material was analysed using Atlas.ti software. In order to analyse the data systematically, a theoretically informed codebook was created, consisting of about 80 codes in total. This codebook consisted of codes derived from previous research that functioned as sensitizing concepts $[6,7,40]$. The codebook was developed and tested by both authors by discussing it at length and performing the preliminary coding together. The preliminary codebook was then piloted on 5 case files, during which additional codes were added, and redundant codes removed in mutual consultation. This way, the codebook was continuously developed and refined. A logbook was kept and memos were written to ensure that the cyclical process of data analysis inherent to qualitative research took place in a systematic and verifiable way $[7,10,26]$. The final codebook consisted of 76 codes, and hence, is the result of both inductive and deductive coding strategies. Examples of codes include means (further subdivided into different types of means including physical force, deceit, etc), vulnerability, recruitment, work situation, work contract, salary, immigration status, immigration motive, motive of the suspect etc. ${ }^{5}$

One case file was coded by both authors to be able to calculate measures for intercoder agreement, providing a Holsti Index of 78,0\% and a Krippendorff's cAlpha Binary of $0,69 .{ }^{6}$ Whereas the coding was done by both authors, the analysis was conducted by the first author, through a process of constant comparison of the content of different codes [18].

\section{Results: Exploitation in Chinese restaurants}

The analysis indicates that the exploitative circumstances that victims reported is the result of a complex interplay of different factors, among which immigration status. The results presented below indicate how different factors work together to create the situations of labour trafficking.

\footnotetext{
${ }^{5}$ A copy of the code book (in Dutch language) is available upon request

${ }^{6}$ These indices indicate to what extent coders select the same text fragments to be coded and then apply the same code on the selected text. The Holsti index represents the percentage of agreement between two coders. The C-Alpha Binary coefficient is applicable if the coders have created quotations themselves, which was the case. The coefficient will tell you for each code whether the different coders have identified similar or the same text fragments in relation to a given code. The C-Alpha Binary coefficient should be above .667 [26], which is the case. In making this calculation, codes were included that could be interpreted in different ways. If codes that are more straightforward in its application to text fragments (such as descriptives) are also included, the CAlpha Binary coefficient rises to $>.95$ which can be considered as very reliable [26].
} 


\section{Before arrival}

\section{Poverty}

All victims except one were legally recruited from China to work in the Netherlands as a cook in a Chinese restaurant. All these victims came to the Netherlands to earn more money than they did in China so they would be better able to support their families. The victims were not among the poorest of the poor in China, but they also did not earn much of a surplus income. They managed to get by but were not satisfied with their earnings, as they did not allow for savings or taking care of extended family members. This is why they had developed an open attitude vis-à-vis going abroad to work. As Tao said: "In China everyone wants a better life, so if you get the chance to go abroad and make money, you take it." So poverty played a role, but not extreme poverty. It seems a certain economic threshold was in place.

\section{Debts related to recruitment}

Victims were inspired to work abroad through the stories of positive experiences that circulated in their social network. Chao, for example, explains: "I had heard stories from friends and acquaintances who had worked in Germany or the Netherlands before. They told me that you could earn more money abroad. They said it could differ per restaurant but on average you could make an amount of 1,400 to 1,800 euro a month." Because of these stories they either looked for a recruitment agency themselves or were introduced to one by people in their social network.

In the literature, recruitment agencies are important in the context of vulnerability to labour trafficking since they charge high fees to workers, leaving them indebted before having even started to work. Also in the cases studied, both the prospective employees and the employers made costs. They both had to make payments to a recruitment agency for the services provided to them, and they also made other expenses. Tao says: "I have paid about 9,000 euro to the recruitment agency in China. Apart from that, I also had to pay for my flight and for some other costs." These other costs usually involve legalization of documents by Chinese institutions. The recruitment agencies do not appear to be very transparent in the costs prospective employees have to make. Tao continues: "In the beginning I did not know that the costs would be this high but once I was in business with the recruitment agency I just continued." Because victims had to make such high costs, once in the Netherlands, they did not want to return to China as they needed to have a certain return on their investment. Cong indicated: "Because I had already paid all this money there was no turning back for me."

\section{Acceptance of exploitative work contracts}

The restaurant owners in the files testify that they do not have any idea about Dutch migration policies and therefore heavily relied on the services of the recruitment agencies. This did not, however, prevent the suspects from making their own separate agreements with the chefs. Victim Cong explained: "I signed two contracts. One was a contract in Dutch that indicated I would make 1.563,90 euro a month before taxes. I signed this contract in China. This labour contract 
was necessary so I could apply for a visa at the Dutch embassy. The second contract was in Chinese. It said I would make 900 euro because I was new." His Dutch contract was a standard contract that followed the Collective Agreement for restaurant personnel, and indicated, amongst other things, that he would work $38 \mathrm{~h}$ a week and that he was entitled to holiday leave and holiday payments. His contract in Chinese on the other hand, read as follows: "The first 1 to 3 months is a training period, during which the most important tasks are dishwashing, cleaning, tidying, mis-en-place preparations, cutting etc. The employer will determine your exact position in the kitchen depending on your results during this training period. The division of labour in Dutch kitchens is not easy. You will have to work together with the entire team, work hard, adopt a modest attitude and show eagerness to learn vis-à-vis the chef." Moreover, the contract also indicated that he would work 6 days a week and that "the work starts at $11 \mathrm{~h}$ and lasts until the last guest leaves, if this is late this does not count as overtime. There is no holiday." Clearly, this arrangement is not allowed under the Collective Agreement for restaurant personnel.

The workers are not handed a copy of the contract in Dutch. In a secretly recorded conversation, Cong confronts his female boss with the salary that he remembers was indicated in the Dutch contract, and she, Hui, says: "What is in that contract is only meant for the government. So you could come to the Netherlands." Julan's experience with the labour contract that gave him permission to work in the Netherlands is similar: "I received a contract in Chinese and in Dutch. I only had to sign the Dutch contract and return it, which I did." He did not get a copy, but once in the Netherlands he asked for it again and did get it. However, the salary on the contract had been removed with Tippex by his employer. Forensic research uncovered that the salary there was in line with the collective agreement for restaurants (almost 1600 euro).

In some cases, migrant workers are offered two contracts, in other cases they only receive the contract in Dutch. During a telephone conversation with the prospective employer the Dutch contract is allegedly explained in Chinese. Of course, the content of the telephone conversation differed from what is in the contract. Chao illustrates: "I was called by Shing, my current boss (...) I was explained that my salary depended on how well I would do my job (...) I had to work $11 \mathrm{~h}$ a day." The idea that chefs will earn more if they perform well is also voiced by Hua: "he told me I would make 600 euro in the beginning and that I would earn 50 or 100 euro more after 2 or 3 months."

In all cases the victims consented to the oral or written contract in Chinese which was exploitative under Dutch law, because they thought they could realise their migration aspirations this way. Chao said: "I thought, I finally get a good opportunity to go and work abroad, I do not want to miss it. So I just signed and barely looked at the contract and signed it in good faith." The formal contracts in Dutch were exclusively meant for the Dutch bureaucracy, which is also evident from the fact that both victims as well as employers had no clue about the Dutch labour laws they were supposed to abide by. Ning for example said: "I have heard about the right to holiday leave and such, but I don't know about this, the bookkeeper knows. (...) I don't keep track of that. I think the workers do that themselves." Suspects also only had vague or no knowledge at all of the Collective Agreement. Furthermore, when asked if they ever had holiday leave or holiday payments, victims indicated that they did not understand the question as they are unfamiliar with the concepts. 


\section{Employer preferences}

The restaurant owners had certain motives to recruit kitchen staff from China and were therefore willing to make costs. Heng explains: "In the last years it has become increasingly difficult to recruit kitchen staff. In the last years, many wok- and sushi restaurants have opened up and this is why it is difficult to find a good chef." Other advantages of recruiting chefs from China are offered by his wife Kyona: "People who come from China get a permit for 3 years so I have them for 3 years on a tenured contract. That is an advantage for us. Chinese people in the Netherlands apply at different restaurants for example to look for better terms of employment. The people from China also have a cooking diploma and the Chinese people in the Netherlands do not all have this."

It is striking that the advantages that the suspects mention regarding the skills and experience that chefs from China bring along, do not appear to play a role in the way recruitment is organized. Tao elaborates: "I did a training there to become a cook and I received a diploma. It was a 3 months training." There was also usually not a job interview but showing "a cooking certificate was enough" (Tao). Hua had been working in the chemical industry all his life. When he learned of the opportunity to work in the Netherlands, he followed a short course to become a cook because he was told he needed a certificate. His boss, Heng remarked on his skills: "I have seen the diploma, so I could see that he had enough training and experience as a chef." Likewise, the suspect Kang contacted a recruitment agency in China to indicate that he "wanted a relatively young cook with diplomas. [The person from the recruitment agency] then gave me three names and sent me their pictures. That is when I picked Cong." There were no job interviews, or exchanges of cooking portfolios or CVs. The only thing that was considered is if there is a valid diploma (which is required by Dutch immigration authorities), as is also evidenced by suspect Liang: "At a certain moment, the recruitment agency informed me that two cooks had been found in China (...) I could not choose between different cooks. I had to take these two." As working experience did not appear to be very relevant, the main reason why the restaurants recruited from China is likely to be the fact that Chinese migrants in the Netherlands with permanent stay seek to negotiate better terms of employment. Hence, the main motive for recruiting in China instead of locally seemed to be financial in nature, which we will also see later in this paper.

From the foregoing, it becomes clear that several pre-arrival factors have contributed to making the exploitative situations possible. First, most of the victims had migrated to the Netherlands because of their desire to create a better financial position for themselves and their family. This has been a powerful motivation for accepting future poor working and living conditions. The victims accepted a (written or oral) work contract that was exploitative under Dutch labour law. They accepted the work contract because they perceived it to be a chance to realise their migration aspirations. This confirms the ideas in the literature on how migrants may knowingly accept exploitative working conditions as being a regular component of migration processes. Furthermore, debts victims owed related to recruitments costs constituted another barrier to escaping the situation and left victims with a feeling of having no possibility of turning back. Moreover, contrary to what suspects stated, their actions indicate that their motivation to hire Chinese migrant workers are of financial nature. This motivation constitutes a main driver and instigator of the exploitation. 


\section{After arrival}

\section{Multiple dependencies}

After arriving in the Netherlands, housing was arranged by the employers, usually at the restaurant itself. The quality of the housing arrangements diverges. It was never more than a room, which in some cases had to be shared with other cooks. There was one case in which the victim could not lock his room, and in one case the victim could not leave the house after the restaurant's opening hours as that would set off the alarm. As the restaurants were located in small cities or villages in the Dutch countryside, victims were not embedded in a local Chinese community. Not being able to communicate with local Dutch people, their social contacts were largely restrained to the restaurant. The victims did have a phone or internet connection which allowed them to communicate with Chinese people living in other places in the Netherlands and with family and friends back home.

After arrival, employers took their employees to a bank to open up an account. As the victims do not speak Dutch, the employers took care of everything and indicated where the victims needed to sign. They also confiscated the bank card and took care of the account's online administration. The account was then used to make the salary payments. This way, the arrangement looked completely legitimate. There was a working permit and residence permit, and salaries were paid into the victims accounts. Everything seemed accounted for to tackle the Dutch bureaucracy.

However, victims could not access their bank accounts. They were paid in cash a much lower amount than was transferred to their bank accounts. Employers also occasionally transferred money to the victim's family in China. Different scenarios then pop up with regard to what they do with the surplus money that is generated in the account. In some cases employers transferred the money to their own account or a third party. Employers also sometimes used the account to make up for the expenses they made for the recruitment agency and immigration fees, so they deduct these costs from the wages of the employees. Guo recollects having paid close to 9,000 euro in China and says: "that is excluding the 3,000 I had to pay in the Netherlands. That 3,000 euro was subtracted from my salary." Suspect Heng argues that he agreed with his victim Hua to pay him 1,300 a month but receive only 500 in cash. He argues that he would pay him the difference at the end of the 36 months contract. Employers perceived this as insurance against their employees returning to China early.

\section{Immigration status}

Whereas almost all the employers kept their employees' bank cards, only a few of them also kept their passports or immigration cards, which contrasts with the image in the literature. It seems that the fact that the work permit, and hence the residence permit, is tied to the employer is what created vulnerability. Both the employers and the victims are highly aware of that. In all cases, an implicit or explicit threat is exercised by the employers, to take the residence status of the victims away. The employers have that power and the workers are highly aware of that. Zhong said: "my boss said that if I left, my residence permit would be taken away by the boss." Because workers are bound to their employers, they basically have only a few choices. They can stay and endure the 
working conditions until they have served their contract, they can go back to China (indebted), or they can run away from their employer and become irregular. As many strive to get a permanent resident permit, the first option seems most attractive from their perspective.

Moreover, as the victims have accumulated debts, the fear of losing their job and hence their income is very important in understanding how victims see no alternative but to endure. Julan explains how, even though he did not like his working conditions, he felt he had no choice but to accept them: "There was no point in going against her (...) If I would not do that she would send me back. I would be out of a job and without income. I had made all kinds of costs such as my flight ticket. I had to earn that back at least."

\section{Working conditions worse than expected}

Most victims start to work within a couple of days after arrival. They usually find the working conditions to be much tougher than anticipated: "I knew it would be tough, but not this tough." (Hua) Because enduring the exploitative circumstances is considered a better option than going back to China or becoming irregular, victims try to negotiate better working conditions. Julan recalls how he had to work about $76 \mathrm{~h}$ per week and 7 days a week during the first year and a half. He says: "Because that was very exhausting, together with some colleagues we asked if we could work less hours." After this, his boss consented to working only about $71 \mathrm{~h}$ a week. He elaborates: "During both periods, the end time was always variable. This depended on the number of guests that was still in the restaurant at $22 \mathrm{~h} . "$

Apart from the number of working hours, which Julan designates as "incomparable to China", the victims are shocked about the speed with which they have to work and the lack of proper breaks. Tao elaborates: "I did not get any breaks. Just 15 min to eat. And even then the boss would comment by saying it almost took us half an hour. The boss said we had to eat faster." And Chao adds: "Each day we have two eating moments of $10 \mathrm{~min}$ to eat sitting down. The intensity of the work here in the Netherlands is much heavier than in China. If I would wait in front of a pan for a dish to cook, the owner would start yelling at me that I had to do more things at the same time. I was not allowed to stand still. We had to work endlessly without sitting down." The accounts offered by victims and witnesses who also have experienced working in the kitchens of Chinese restaurants in the Netherlands, demonstrate that at least part of the exploitation they perceive occurs through the medium of time. Axelsson et al. [4], analyzing work-time arrangements in Chinese kitchens in Sweden, arrive at a similar conclusion. They argue that precarious work-time arrangements "not only have to do with the number of hours worked on a daily and annual basis but also with the pace and intensity of work and the uncertainty about when work will take place" (Axelsson 2015: 174).

Before migrating, victims knew from the contracts they signed that they would be working a lot and accepted that their overtime hours would not be compensated. In other words, they partially accepted the - from a Dutch perspective - exploitative circumstances. However, they perceived the working conditions to be much worse than they anticipated. They endured them for some time because they considered this the best option considering their migration aspirations and their debts. 


\section{Earning the transfer to permanent residence}

The hierarchy in Chinese restaurants in the Netherlands requires chefs to start at the bottom and work your way up. Chinese culture stipulates you have to show loyalty, and only afterwards you can start to deserve a higher pay ore a residence permit [20]. The victims also had to start at the bottom of the hierarchy in the kitchen, even though most of them were recruited as a higher level chef. Cong, who was hired as a dim sum chef, testified: "for the most part of my time I had cleaning tasks. Everything except for making dim sum. (...) I was actually more of a cleaner." His employer, Kang, acknowledges this: "Because he was new he had to do different things. Start from scratch. He used to be a chef in China and he also got his work permit because of his profession, but still he had to learn everything from scratch." Hua, who had taken a 3 months training in order to qualify for immigration, said: "I had to learn cooking again from scratch. The training had been useless."

Hiah and Staring [20], likewise show that Chinese restaurant owners and their employees operate in a 'moral economy', in which labour relations are influenced by such informal rules and culturally shared expectations about reciprocity. Guanxi is the Chinese term for the way in which interpersonal relationships are interpreted. Building guanxi is about strengthening the personal relationship between two parties and based on the idea of valuing a long-term relationship between the parties and going beyond immediate goals. This is vital to understanding how Chinese people recruit employees ([20]: 88).

The idea of guanxi not only expects a long working period for workers to become deserving of doing more complicated tasks, but also of becoming deserving of a permanent residence permit. Suspect Shing, in a conversation that was secretly taped by victim Guo, explains: "you have to work 10 years for the person who does your residence application to get a residence permit. You have to work 10 years for the boss for a very low salary." Suspects therefore sometimes tried to stretch the period during which workers depended on them by negotiating a new exploitative contract once the first contract had been served. A witness, Peng, (friend of the suspect Shing who also owns a restaurant) says: "it happens more often with Chinese cooks that when the contract expires or when the work permit has to be renewed, that they take off. With [a new permit] they can go where they want and they are no longer tied to the restaurant where they work. That is why terms have to be negotiated before the new permit is applied for. That is normal."

Guo had worked in his employers restaurant for 3 years and was now eligible for a 5 -year permit that does not tie him to any employer in particular. His employer wanted him to sign a new contract, declaring he would work for him exclusively for 5 more years under exploitative circumstances. Moreover, the contract stipulated that the employer would not pay him in full, part of his salary would be withheld from him and only paid if he served his full contract. Shing, Guo's employer, indicated that this was just to give him "a sense of security." When asked by the interrogator what he meant with that he said: "I wanted him to stay and work with me. (...) I was afraid that he would leave." Shing exercised pressure by threatening to declare Guo's residence permit invalid if he would not sign the contract. This shows that the common threats related to immigration come from a desire by the employer to keep their relatively cheap and docile staff. Moreover, this desire is legitimized by the idea of Guangxi: the workers need to remain cheap and docile for a longer period than what is stipulated by immigration policies to become deserving. 
Witnesses with experience in the Chinese restaurant sector suggest that this practice is not limited to the restaurants in the files. Hu, a former co-worker from Zhong, who has a permanent residence permit testified that once employees have a permanent residence permit, they may start to renegotiate their terms. As a result, they are no longer seen as attractive workers for the restaurants. He elaborates: "On his (Zhong's) salary check it is stated that he received 1,000 euro a month but he receives 500 or 600 . (...) This is what happens to people who arrive from China. The restaurant owners want them because they are cheap. (...) as soon as people arrive from China on a work permit the workers with a permanent residence permit have to leave. This is the reason why people with a permanent residence permit often switch restaurants. The employer especially prefers the cheaper labour force. (...) this happened to me too, I lost my job because of this."

Axelsson et al. [4] likewise found that employers prefer to replace workers with a permanent residence permit and recruit new staff from China, as their salaries are lower and they are more likely to accept precarious work-time arrangements. Hiah and Staring [20] add: "Many regular Chinese employees whilst already working longer hours than a regular nine to five job, are reluctant to work overtime". The witness Mulan, who is herself also a restaurant owner, neatly summarizes the interests of the workers and the restaurant owners: "The boss does not want to pay too much and the worker just wants to stay in the Netherlands."

\section{Conclusion}

This paper has corroborated the idea that human trafficking situations are "not simply a matter of bad employers tricking and coercing unlucky workers: unfree labour relations are systematically institutionalized by state immigration policies" ([41]: 205). At the same time, it is not just immigration policies acting on their own. The vulnerability of temporary labour migrants to exploitation is the result of an interplay of several factors, including language barriers and social isolation. However, immigration policies clearly set the scene. The findings align with Tyldum's work who understands trafficking "as systematic exploitation of vulnerabilities inherent in migration. These vulnerabilities are not the creation of traffickers or exploiters, but are produced by underlying factors such as poverty and economic inequality, discrimination against women, and lack of opportunities for migration. However, these vulnerabilities create an arena that makes exploitation possible, and one that traffickers can manipulate to keep their victims in a situation where continued exploitation is possible." ([43]: 107).

It was illustrated how temporary labour migrants are more vulnerable than other workers because they are subjected to immigration policies, and how immigration policies have disciplinary functions and shape relationships in the labour market (see also [3]). For example, employers are empowered by the fact that temporary labour migrants are dependent on them for their work and residence permit. Because of that, workers are hesitant to disobey or run away. Furthermore, many temporary labour migrants are vulnerable to exploitation because they have invested large amounts of money in realising their migration ambitions. The workers see exploitative circumstances as a normal component of their migration, and the employers recruited their victims this way to get cheap and docile staff. Another reason for these labour migrants 
to continue working for their bosses even under harsh conditions, is that after their temporary working permit expires they can apply for a permanent permit that allows them to switch employer. Hence, "the lens required to understand and explain unfree migrant labour should encompass both transnational migrant processes and processes of exclusion practiced by states ([29]: 589).

It is by no means our intention to argue that employer sponsored temporary migration programmes should be cancelled. After all, limiting such options could lead to an increase in informal forms of migrant worker recruitment [56]. Moreover, it has not been the intention to argue that it is only immigration policies that foster exploitation. In contrast, we should not only look at immigration policies to understand how exploitative work situations are produced and sustained, but consider how immigration policies interact with and provide room for other factors to play a role [4]. After all, this paper has shown how the exploitative situations the victims found themselves in resulted from the ways in which both the employers and the victims manoeuvre the space provided by the policies. Whereas immigration policies restrict the mobility of migrant workers, they also provide them with opportunities they would not have otherwise. Maintaining good relationships with the employer is part of victim's long term strategy to achieve guanxi to realise longterm economic goals [4]. Policymakers should be highly aware of the vulnerabilities of temporary labour migrants' positions created by such policy arrangements.

The results presented here provide insight in labour trafficking in a specific sector in the Netherlands. Due to the nature of the data, the results of this qualitative research cannot be generalized to all cases of labour exploitation. It therefore remains important to continue the work on labour trafficking as this area is still profoundly under researched [8]. It is pertinent to do more qualitative research of other case studies (other countries, other sectors) to investigate how immigration policies set the scene there in creating a different or similar space in which distinct factors re facilitated in working together to foster exploitative practices. Furthermore, it is recommendable to test the ideas from such studies on lager scale datasets using quantitative research techniques [8].

Open Access This article is distributed under the terms of the Creative Commons Attribution 4.0 International License (http://creativecommons.org/licenses/by/4.0/), which permits unrestricted use, distribution, and reproduction in any medium, provided you give appropriate credit to the original author(s) and the source, provide a link to the Creative Commons license, and indicate if changes were made.

\section{References}

1. Ahmad, A. (2015). Since many of my friends were working in the restaurant: The dual role of immigrants' social networks in occupational attainment in the Finnish labour market. Journal of International Migration and Integration, 16(4), 965-985.

2. Althoff, M. (2013). Multiple identities and crime. A study of Antillean women and girls in the Netherlands. European Journal of Criminology, 10(4), 394-407.

3. Anderson, B. (2010). Migration, immigration controls and the fashioning of precarious workers. Work, Employment and Society, 24(2), 300-317.

4. Axelsson, L., Malmberg, B., \& Zhang, Q. (2015). On waiting, work-time and imagined futures: Theorizing temporal precariousness among Chinese chefs in Sweden's restaurant industry. Geoforum, 78, 169-178.

5. Bloch, A., \& McKay, S. (2013). Hidden dishes - How food gets on to our plates: Undocumented migrants and the restaurant sector. Journal of Workplace Rights, 17(1), 69-91.

6. Blumer, H. (1969). Symbolic interactionism. Perspective and method. Berkeley: University of California Press. 
7. Charmaz, K. (2009). Constructing grounded theory. A practical guide through qualitative analysis. London: Sage.

8. Cockbain, E., Bowers, K., \& Dimitrova, G. (2018). Human trafficking for labor exploitation: The results of a two-phase systematic review mapping the European evidence base and synthesizing key scientific research evidence. Journal of Experimental Criminology, 14, 319-360. https://doi.org/10.1007/s11292-017-9321-3.

9. Consterdine, E. Samuk, S. (2018) Temporary migration programmes: The cause of antidote of migrant worker exploitation in UK agriculture. Journal of International Migration and Integration, 19, 1005. https://doi.org/10.1007/s12134-018-0577-x.

10. Corbin, J., \& Strauss, A. (1990). Grounded theory research. Procedures, canons, and evaluative criteria. Qualitative Sociology, 13(1), 3-21.

11. Cranford, C. J. (2005) Networks of exploitation. Immigrant labor and the restructuring of the Los Angelos janitorial industry. Social Problems, 52(3), 379-397.

12. De Bie, J., Poot, D., \& Van der Leun, J. (2014). Jihadi networks and the involvement of vulnerable immigrants. Reconsidering the ideological and pragmatic value. Global Crime, 15(3/4), 275-298.

13. De Haas, H. (2010). The internal dynamics of migration processes: A theoretical inquiry. Journal of Ethnic and Migration Studies, 36(19), 1587-1617.

14. De Jonge van Ellemeet, H. (2007). Slecht werkgeverschap of 'moderne slavernij'; handhaving van een nader af te bakenen verbod. Justitiële verkenningen, 33(7), 107-119.

15. Dwyer, P., Lewis, H., Scullion, L., \& Waite, L. (2011). Forced labour and UK immigration policy: Status matters? York: Joseph Rowntree Foundation.

16. Esser, L. B., \& Dettmeijer-Vermeulen, C. E. (2016). The prominent role of National Judges in interpreting the international definition of human trafficking. Anti-Trafficking Review, 6, 91.

17. Garcés-Mascareñas, B. (2015). Revisiting bordering practices: Irregular migration, Borders, and citizenship in Malaysia. International Political Sociology, 9(2), 128-142.

18. Glaser, B. G., \&, A. L. Strauss ([1967] 2006) The discovery of grounded theory. Strategies for qualitative research. New Brunswick: Aldine Transaction.

19. Goodey, J. (2008). Human trafficking: Sketchy data and policy responses. Criminology and Criminal Justice, 8(4), 421-442.

20. Hiah, J., \& Staring, R. (2016). 'But the Dutch would call it exploitation'. Crimmigration and the moral economy of the Chinese catering industry in the Netherlands. Crime, Law and Social Change, 66(1), 83-100.

21. Hynes, P. (2010). Global points of 'vulnerability': Understanding processes of the trafficking of children and young people into, within and out of the UK. The International Journal of Human Rights, 14(6), 952-970. https://doi.org/10.1080/13642987.2010.512140.

22. Kleemans, E. R. (2007). Organized crime, transit crime, and racketeering. Crime and Justice, 35(1), $163-215$.

23. Kleemans, E. R., \& Brienen, M. E. I. (2001). Van vriendendienst tot slangenkop. Een analyse van tien opsporingsonderzoeken naar mensensmokkel [From kind turns to snakeheads. An analysis of ten police investigations into human smuggling]. Tijdschrift voor Criminologie, 43(4), 350-359.

24. Kleemans, E. R., Brienen, M. E. I., \& van de Bunt H. G. (2002) Georganiseerde criminaliteit in Nederland. Tweede rapportage op basis van de WODC monitor [organized crime in the Netherlands. Second report based upon the WODC monitor]. The Hague: Wetenschappelijk Onderzoek en Documentatiecentrum.

25. Knotter, J., Korf, D. J., \& Lau, H. Y. (2009). Slangenkoppen en tijgerjagers. Illegaliteit en criminaliteit onder Chinezen in Nederland. Den Haag: Boom Juridische Uitgevers.

26. Krippendorff, K. (2004). Content analysis. An introduction to its methodology. London: Sage.

27. Lenard, P., \& Streahle, C. (2010). Temporary labour migration: Exploitation, tool of development, or both? Policy and Society, 29(4), 283-294.

28. Lenard, P., \& Streahle, C. (2011). Temporary labour migration, global redistribution, and democratic justice. Politics, Philosophy \& Economics, 11(2), 206-230.

29. Lewis, H., Dwyer, P., Hodkinson, S., \& Waite, L. (2015). Hyper-precarious lives: Migrants, work and forced labour in the global north. Progress in Human Geography, 39(5), 580-600.

30. MacKenzie, R., \& Forde, C. (2009). The rhetoric of the 'good worker' versus the realities of employers' use and the experiences of migrant workers. Journal Indexing and Metrics, 23(1) 142-159.

31. Maher, S. (2018). Out of West Africa: Human smuggling as a social Enterprise. The Annals of the American Academy of Political and Social Science, 676(1), 36-56. https://doi.org/10.1177/0002716217743935.

32. Portes, A. (1998). Social capital: Its origins and applications in modern sociology. Annual Review of Sociology, 24, 1-24.

33. Postma, D. and Van Wijk, J. (2012) Op het land in plaats van achter het raam. Aard en omvang van arbeidsuitbuiting in Nederland. PROCES, 91(5): 327-339.

34. Roosblad, J., Ganzinga, M, Plooij, P. and Scholten, T. (2017) Nationaal Dreigingsbeeld 2017. Mensenhandel - Arbeidsuitbuiting, criminele uitbuiting en gedwongen dienstverlening, Den Haag: iSZW. 
35. Ruhs, M. (2015). The price of rights. Regulating international labor migration. Princeton: Princeton University Press.

36. Ruhs, M., \& Anderson, B. (2010). Semi-compliance and illegality in migrant labour markets: An analysis of migrants, employers and the state in the UK. Population, Space and Place, 16, 195-211.

37. SCP. (2011). Chinese Nederlanders: van horeca naar hogeschool. Den Haag: Sociaal Cultureel Planbureau.

38. Skrivankova, K. (2010). Between decent work and forced labor: Examining the continuum of exploitation. York: Joseph Rowntree Foundation.

39. Staring. (2009). Different methods to study irregular migration. In I. Van Liempt \& V. Bilger (Eds.), The ethics of migration research methodology. Dealing with vulnerable immigrants (pp. 83-97). Sussex: Sussex Academic Press.

40. Strauss, A. L., \& Corbin, J. (1990). Basics of qualitative research. Techniques and procedures for developing grounded theory. Thousand Oaks: Sage.

41. Strauss, K., \& McGrath, S. (2017). Temporay migration, precarious employment and unfree labour relations: Exploring the 'continuum of exploitation' in Canada's temporary foreign worker program. Geoforum, 78, 199-208.

42. Sumpton, M. (2019) Is employer sponsorship a good way to manage labour migration? Implications for post-Brexit migration policies. National Institute Economic Review, no 248 May 2019.

43. Tyldum, G. (2013). Dependence and human trafficking in the context of transnational marriage. International Migration, 51(4), 103-115.

44. Van der Leun, J., \& van Schijndel, A. (2016). Emerging from the shadows or pushed into the dark? The relation between the combat against trafficking in human beings and migration control. International Journal of Law, Crime and Justice, 44, 26-42. https://doi.org/10.1016/j.ijlcj.2015.04.001.

45. Van der Leun J.P. \& Vervoorn L. (2004), Slavernij-achtige uitbuiting in Nederland. Een inventariserende literatuurstudie in het kader van de uitbreiding van de strafbaarstelling van mensenhandel. In: Meijersreeks, nr. 82. Den Haag: Boom Juridische uitgevers.

46. Van Eijl, C. (2012), Tussenland: Illegaal in Nederland, 1945-2000. Historische Migratiestudies 2. Hilversum: Verloren.

47. Van Koppen, V. (2013). Pathways into organized crime: Criminal opportunities and adult-onset offending. Amsterdam: VU University Amsterdam.

48. Van Meeteren, M. (2014). Irregular migrants in Belgium and the Netherlands: Aspirations and incorporation. Amsterdam: Amsterdam University Press.

49. Van Meeteren, M., \& Hiah, J. (2019). Self-identification of victimization of labor trafficking. In J. A. Winterdyk \& J. Jones (Eds.), The Palgrave international handbook of human trafficking. Cham: Palgrave MacMillan.

50. Van Meeteren, M., \& Pereira, S. (2018). Beyond the 'migrant network'? Exploring assistance received in the migration of Brazilians to Portugal and the Netherlands. Journal of International Migration and Integration, 19(4), 925-944.

51. Van Meeteren, M., van de Pol, S., Dekker, R., Engbersen, G., \& Snel, E. (2013). Destination Netherlands. History of immigration and immigration policy in the Netherlands. In J. Ho (Ed.), Immigrants: Acculturation, socioeconomic challenges and cultural psychology (pp. 113-170). Hauppage: Nova Science Publishers.

52. Vogiazides, L., \& Hedberg, C. (2013). Trafficking for forced labour and labour exploitation in Sweden: Examples from the restaurant and the berry industries. In N. Ollus, A. Jokinen, \& M. Joutsen (Eds.), Exploitation of migrant Workers in Finland, Sweden, Estonia and Lithuania (pp. 171-237). European Institute for Crime Prevention and Control: Helsinki.

53. Weenink, D. (2014). Frenzied attacks. A micro-sociological analysis of the emotional dynamics of extreme youth violence. British Journal of Sociology, 65(3), 411-433.

54. Weitzer, R. (2014). New directions in research on human trafficking. The Annals of the American Academy of Political and Social Science, 653(1), 6-24. https://doi.org/10.1177/0002716214521562.

55. Witkamp, A., Linssen, M. (2016) Functie-eisen Aziatische horeca. Zijn eisen wat betreft kennis van taal en cultuur reeel en proportioneel? Zoetermeer: Panteia, research to progress.

56. Wright, C.f., Groutsis, D., \& van den Broek, D. (2017). Employer-sponsored temporary labour migration schemes in Australia, Canada and Sweden: Enhancing efficiency, compromising fairness? Journal of Ethnic and Migration Studies, 43(11), 1854-1872.

Publisher's note Springer Nature remains neutral with regard to jurisdictional claims in published maps and institutional affiliations. 